1

Yudhanta Shambara K., Nurul Kompyurini ～InFestasi Vol.12, No.2, Desember 2016

\title{
MEMPREDIKSI KECENDERUNGAN PERUSAHAAN MELAKUKAN PENGHINDARAN PAJAK
}

\author{
Yudhanta Sambharakreshna \\ Nurul Kompyurini \\ Universitas Trunojoyo Madura \\ y_sambharakreshna@yahoo.com
}

\begin{abstract}
This study aimed to analyze and predict the executive character, profitability, and corporate governance to tendency of company doing tax avoidance. Samples are 45 companies joined in 45 LQ Indonesia Stock Exchange during 2009 until 2013. Samples were selected using purposive sampling method. Data was analyzed using descriptive analysis method, multiple linear regression, hypothesis testing. The results of this study indicate that the character of executives and profitability affect to the tax avoidance, while the audit committee and independent commissioner has no effection to the tax avoidance.
\end{abstract}

Keywords : executive character, profitability, corporate governnace, tax avoidance.

\begin{abstract}
Abstrak
Tujuan penelitian ini yaitu untuk menganalisis dan memprediksi karakter eksekutif, profitabilitas, dan tata kelola perusahaan terhadap kecenderungan perusahaan melakukan penghindaran pajak. Sampel penelitian berjumlah 45 perusahaan yang tergabung dalam LQ 45 di Bursa Efek Indonesia selama 2009 - 2013. Teknik pengambilan sampel menggunakan metode purposive sampling. Analisis data penelitian menggunakan analisis deskriptif, regresi linear berganda dan pengujian hipotesis. Hasil penelitian menunjukkan bahwa karakter eksekutif dan profitabilitas dapat memprediksi kecenderungan perusahaan untuk melakukan penghindaran pajak, sedangkan komite audit dan komisaris independen tidak dapat memprediksi kecenderungan perusahaan untuk melakukan penghindaran pajak.
\end{abstract}

Kata Kunci: Karakter eksekutif, profitabilitas, tata kelola perusahaan, penghindaran pajak

\section{PENDAHULUAN}

Pajak merupakan kontribusi wajib dari warga negara kepada Negara dimana pajak memiliki sifat yang memaksa berdasarkan ketentuan perundang-undangan. Pajak bagi pengusaha selalu dianggap beban karena pajak bisa mengurangi pendapatan perusahaan. Pajak juga mempengaruhi pemegang saham untuk melakukan penghindaran pajak dengan tujuan untuk mengurangi beban pajak terhadap pendapatan yang diperolehnya.

Penghindaran pajak dalam hal ini bukan semata mata perusahaan tidak melakukan pembayaran pajak, melainkan mereka mengurangi jumlah pajak yang harus dibayarkan seseuai dengan ketentetuan perpajakan. Upaya penghindaran pajak tersebut seringkali dilakukan oleh perusahaan dengan tujuan untuk efisiensi biaya/beban pajak. Terdapat beberapa faktor yang mempengaruhi manajemen melakukan penghindaran pajak yakni karakter eksekutif, profitabilitas, dan corporate governance.

Karakter eksekutif mengasumsikan bahwa pimpinan perusahaan sebagai pengambil kebijakan pasti memiliki karakter yang berbeda-beda. Pemimpin perusahaan yang memiliki karakter risk taker dan risk averse tercermin pada besar kecilnya risiko perusahaan yang ada (Budiman dan Setiyono, 2012). Semakin tinggi risiko suatu perusahaan, maka eksekutif cenderung bersifat risk taker. Sebaliknya, semakin rendah risiko suatu perusahaan, maka eksekutif cenderung bersifat risk averse.

Profitabilitas merupakan salah satu pengukuran bagi kinerja suatu perusahaan. Profitabilitas terdiri dari beberapa rasio, salah satunya adalah return on assets (ROA). Perusahaan yang memperoleh laba diasumsikan tidak melakukan penghindaran pajak (tax avoidance) karena mampu mengatur pendapatan dan pembayaran pajaknya (Maharani dan Suardana, 2014), tetapi tidak semua perusahaan tidak melakukan penghindaran pajak, karena penghindaran pajak dilakukan untuk memperkecil pembayaran pajak penghasilan perusahaan.

Selain Karakter eksekutif dan profitabilitas, terdapat keterkaitan corporate governance terhadap penghindaran pajak. Tata kelola perusahaan atau Corporate governance menjelaskan hubungan antara berbagai partisipan dalam perusahaan yang menentukan arah kinerja perusahaan (Haruman, 2008). Corporate governace dapat meningkatan nilai tambah bagi para pemegang saham, hal ini bisa disimpulkan bahwa semakin baik mekanisme corporate 
governance yang dilakukan oleh perusahaan maka nilai tambahnya akan semakin besar (Friese, 2006 dalam Sari, 2014). Perusahaan yang memiliki tata kelola yang buruk memungkinkan melakukan penghindaran pajak.

Makalah ini mengintegrasikan beberapa penelitian sebelumnya serta menganalisis kembali pengaruh karakter eksekutif, profitabilitas dan corporate governance terhadap penghindaran pajak. Pengukuran penghindaran pajak dalam makalah ini tidak menggunakan effective tax rate (ETR) tetapi menggunakan cash effective tax rate (CETR). Pengukuran cash effective tax rate (CETR) dilakukan dengan cara membandingkan pembayaran pajak secara tunai atas laba perusahaan (Sari, 2014).

\section{Teori Keagenan}

Teori keagenan merupakan teori yang mendasari hubungan kontrak antar anggota-anggota dalam perusahaan, dimana prinsipal dan agen sebagai pelaku utama. Definisi dari agency theory dikemukakan oleh (Scott, 2000) sebagai berikut: "Agency theory is a branch of game theory that studies the design of contracts to motivate a rational agent to act on behalf of principal when the agent's interests would otherwise conflict with those of the principal.".

Prinsipal merupakan pihak yang memberikan mandat kepada agen untuk bertindak atas nama prinsipal, sedangkan agen merupakan pihak yang diberi amanat oleh prinsipal untuk menjalankan perusahaan. Teori agensi juga menjelaskan adanya konflik antara pemilik dan manajemen perusahaan. Prakosa (2014) menjelaskan bahwa konflik tersebut juga terjadi terhadap kepentingan atas laba perusahaan antara pemungut pajak (fiskus) dengan pembayar pajak (manajemen perusahaan). Fiskus berharap adanya pemasukan sebesar-besarnya dari pemungutan pajak, sementara dari pihak manajemen berpandangan bahwa perusahaan harus menghasilkan laba yang cukup signifikan dengan beban pajak yang rendah. Dua sudut pandang berbeda inilah menyebabkan konflik antara fiskus sebagai pemungut pajak dengan pihak manajemen perusahaan sebagai pembayar pajak.

\section{Penghindaran Pajak (Tax Avoidance)}

Tax avoidance merupakan suatu cara untuk meminimalkan beban pajak perusahaan dengan tidak melanggar undangundang serta penghindaran pajak ini merupakan hal yang bersifat legal. Manfaat utama yang diperoleh dari penghindaran pajak adalah untuk penghematan pajak yang lebih besar. Penghematan ini memang menjadi keuntungan bagi pemegang saham.

\section{Karakter Eksekutif}

Budiman dan setiyono (2012) menyatakan bahwa karakter eksekutif ditunjukkan oleh seorang pemimpin perusahaan yang bisa saja memiliki karakter risk taker atau risk averse. Karakter tersebut tercermin dari besar kecilnya risiko perusahaan. Semakin tinggi risiko suatu perusahaan, maka eksekutif cenderung bersifat risk taker. Sebaliknya, semakin rendah risiko suatu perusahaan, maka eksekutif cenderung bersifat risk averse. Karakter eksekutif merupakan karakter dari pimpinan perusahaan yang mempunyai wewenang dan kebijakan dalam pengambilan keputusan dalam perusahaan. Pemimpin perusahaan yang bersifat risk taker akan cenderung lebih berani dalam mengambil keputusan walaupun keputusan tersebut berisiko tinggi ehingga karakter eksekutif diasumsikan sebagai penentu besar kecilnya resiko perusahaan.

Hartono (2008) dalam Budiman dan setiyono (2012) menyatakan bahwa resiko ada kaitanya dengan return yang diperoleh perusahaan. Resiko merupakan penyimpangan atau deviasi dari outcome yang diterima dengan yang diekspektasi. Dengan demikian dapat diartikan semakin besar deviasi antara outcome yang diterima dengan diekspektasikan mengindikasikan semakin besar pula resiko yang ada.

Coles al al, (2004) dalam Budiman dan Setiyono (2012) menyebutkan bahwa risiko perusahaan (corporate risk) merupakan cermin dari kebijakan yang diambil oleh pimpinan perusahaan. Policy yang diambil pimpinan perusahaan bisa mengindikasikan apakah mereka memiliki karakter risk taking atau risk averse. Semakin tinggi corporate risk maka eksekutif semakin memiliki karakter risk taker, demikian sebaliknya.

Pemimpin perusahaan yang bersifat risk taker akan cenderung lebih berani dalam mengambil keputusan walaupun keputusan tersebut berisiko tinggi (Dewi dan Jati, 2014). Sesuai dengan uraian sebelumnya maka hipotesis penelitian dinyatakan sebagai berikut "Perusahaan yang memiliki karakter eksekuti risk taker cenderung melakukan penghindaran pajak".

\section{Profitabilitas}

Profitabilitas merupakan rasio untuk menilai kemampuan perusahaan dalam mencari keuntungan. Rasio ini juga memberikan ukuran tingkat efektifitas manajemen suatu perusahaan. Hal ini ditunjukkan oleh laba yang dihasilkan dari penjualan dan pendapatan investasi. Pada dasarnya penggunaan rasio ini menunjukkan tingkat efesiensi suatu perusahaan. Menurut Nofrita (2013) profitabilitas perusahaan merupakan kemampuan perusahaan dalam menghasilkan laba bersih dari aktivitas yang dilakukan pada suatu periode akuntansi. Pengukuran profitabilitas adalah dengan menggunakan Return On Asset (ROA). ROA memiliki keterkaitan dengan laba bersih perusahaan dan pengenaan pajak penghasilan untuk perusahaan (Kurniasih dan Sari, 2013). Semakin tinggi profitabilitas perusahaan akan semakin tinggi pula laba bersih perusahaan yang dihasilkan dan perusahaan tersebut dapat dikatakan baik.

Profitabilitas merupakan gambaran kinerja keuangan perusahaan dalam menghasilkan laba dari pengelolaan aktiva yang dikenal dengan Return On Asset (ROA). ROA 
merupakan pengukur keuntungan bersih yang diperoleh dari penggunaan aktiva. Semakin tinggi nilai dari ROA, berarti semakin tinggi nilai dari laba bersih perusahaan dan semakin tinggi profitabilitasnya (Prakosa, 2014).

Apabila kemampuan perusahaan menghasilkan laba meningkat maka laba operasional perusahaan juga akan meningkat dan nilai pajak juga meningkat oleh karena inilah profitabilitas berpengaruh terhadap tax avoidance, tapi apabila laba meningkat penghindaran pajak menurun hal ini disebabkan oleh perusahaan tidak melakukan tindakan efisiensi dalam pembayaran pajaknya (Agusti, 2014). Berdasarkan uraian tersebut maka hipotesis penelitian dinytakan sebagai berikut "Perusahaan yang memiliki profitabilitas yang tinggi cenderung melakukan penghindaran pajak".

\section{Corporate governance}

Corporate Governance didefinisikan sebagai efektivitas mekanisme yang bertujuan meminimumkan konflik keagenan, dengan penekanan khusus pada mekanisme legal yang mencegah dilakukannya ekspropriasi atas pemegang saham minoritas (Agusti, 2014). Corporate governance atau tata kelola perusahaan diharapkan mampu meningkatkan nilai tambah perusahaan. Lemahnya mekanisme Corporate governance turut menjadi faktor ambruknya perekonomian dunia tahun 2008 sehingga corporate governance diperlukan untuk mengendalikan perilaku pengelola dana perusahaan agar bertindak tidak hanya menguntungkan dirinya sendiri, tetapi juga menguntungkan pemilik perusahaan, atau dengan kata lain untuk menyamakan kepentingan antara pemilik perusahaan dengan pengelola perusahaan. Dalam FCGI (2000) Mekanisme Corporate governance meliputi komite audit dan dewan komisaris independen.

Komite audit adalah seseorang yang dipilih oleh dewan komisaris untuk melakukan tugas khusus yang mempunyai keahlian dalam bidang akuntansi dan keuangan serta mampu untuk memberikan kontribusi yang baik terhadap perusahaan. Keberadaan komite audit diharapkan mampu meningkatkan kualitas pengawasan internal perusahaan. Selain itu komite audit diharapkan mampu mengoptimalkan mekanisme checks and balances (sistem pengawasan keseimbangan), yang pada akhirnya ditujukan untuk memberikan perlindungan yang optimum kepada para pemegang saham dan stakeholder lainnya (IKAI, 2010). Komite audit merupakan salah satu bentuk nyata dari penerapan good corporate governance atau tata kelola yang baik. Sehubungan dengan komite audit tersebut maka hipotesis penelitian dinyatakan sebagai berikut "Perusahaan yang memiliki komite audit cenderung tidak melakukan penghindaran pajak".

Dewan komisaris independen merupakan seorang dewan komisaris yang bebas dari bisnis dan aktivitas lainnya dengan mengutamakan kepentingan perusahaan dan bertugas untuk mengawasi pengelolaan perusahaan.
Dewan komisaris dapat terdiri dari satu orang atau lebih. Dewan komisaris merupakan majelis, sehingga dalam hal dewan komisaris terdiri atas lebih dari 1 (satu) orang anggota, maka setiap anggota dewan komisaris tidak dapat bertindak sendiri-sendiri, melainkan berdasarkan keputusan dewan komisaris.

Komisaris independen merupakan pihak yang tidak terafiliasi dengan pemegang saham pengendali, anggota direksi dan dewan komisaris lain. Dalam hal ini dewan komisaris tidak boleh melibatkan diri dalam tugas-tugas manajemen dan tidak boleh mewakili perusahaan dalam transaksi-transaksi dengan pihak ketiga. Sub prinsip ini menyatakan dua elemen penting dari tanggung jawab pengelolaan dewan, yaitu kewajiban kehati-hatian dan kewajiban kesetiaan. Semakin banyak komisaris independen maka pengawasan manajemen akan semakin ketat (khoirunnisa, 2014). Pengaruh komisaris independen terhadap penghindaran pajak perusahaan dapat dijelaskan semakin banyak jumlah komisaris independen maka semakin besar pengaruhnya untuk melakukan pengawasan kinerja manajemen(Agustin, 2014). Berdasarkan uraian tersebut maka hipotesis penelitian dinyatakan sebagai "Perusahaan yang memiliki jumlah dewan komisaris independen yang sedikit cenderung melakukan penghindaran pajak.

\section{METODE PENELITIAN}

\section{Jenis Penelitian}

Jenis penelitian yang digunakan dalam penelitian ini adalah penelitian kuantitatif. Menurut (Indrianto dan Supomo, 2002: 2) paradikma kuantitatif atau penelitian kuantitatif menekankan pada pengujian teori-teori melalui pengukuran variabel penelitian dengan angka dan melakukan analisis data dengan prosedur statistik.

\section{Populasi dan Sampel}

Populasi yang digunakan dalam penelitian ini adalah semua perusahaan yang terdaftar di LQ 45 pada BEI selama periode 2009-2013. Perusahaan yang menjadi sampel penelitian ini dipilih berdasarkan kriteria-kriteria tertentu (purposive sampling). Berdasarkan kriteria yang telah ditetapkan, maka jumlah sampel yang digunakan dalam penelitian ini adalah 21 perusahaan dengan periode pengamatan masing-masing perusahaan selama 5 tahun sehingga pada penelitian ini terdapat 105 item observasi.

\section{Variabel Penelitian}

\section{Penghindaran Pajak}

Penghindaran pajak, merupakan usaha untuk mengurangi, atau bahkan meniadakan hutang pajak yang harus dibayar perusahaan dengan tidak melanggar undang-undang yang ada. Untuk mengetahui apakah perusahaan masih melakukan peminimalan pajak digunakan model Cash 
Effective Tax Rate (CETR) yang diharapkan mampu mengidentifikasi keagresifan perencanaan pajak perusahaan yang dilakukan menggunakan perbedaan tetap maupun perbedaan temporer Chen et al. (2010) dalam Prakosa (2014) denganrumus sebagai berikut :

\section{Karakter Eksekutif}

Untuk mengukur seberapa berani eksekutif perusahaan dalam mengambil resiko digunakan pengukuran menurut paligorova (2010) dalam (Carolina, 2014). Paligorova (2010) menyatakan bahwa standar deviasi dari laba sebelum bunga, pajak, depresiasi, dan amortisasi (earning before in terest, tax, depreciation and amortization/EBITDA) di bagi dengan total aset akan menunjukkan penyimpangan terhadap laba. Semakin besar standar deviasi dari EBITDA/total aset menunjukkan semakin besar penyimpangan terhadap laba. Besarnya penyimpangan terhadap laba menunjukkan resiko perusahaan (corporate risk) yang besar pula atau dengan kata lain eksekutif perusahaan semakin berani mengambil resiko.

\section{Profitabilitas}

Diproksikan dengan menggunakan Return On Asse tyaitu perbandingan antara laba bersih dengan total aset pada akhir periode, yang digunakan sebagai indikator kemampuan perusahaan dalam menghasilkan laba (Kurniasih dan Sari,2013), dengan menggunakan rumus sebagai berikut:

\section{Corporate Governance}

Diukur dengan dua proksi, yakni proksi komposisi komisarisin dependen dan proksi keberadaan komite audit. Proksi komposisi komisaris independen diukur menggunakan persentase jumlah komisaris independen terhadap jumlah total komisaris dalam susunan dewan komisaris perusahaan sampel tahun amatan (Andriyani, 2008). Variabel komite audit diukur dengan jumlah total anggota komite dalam suatu perusahaan (Hanum dan Zulaikha, 2013).

\section{Teknik Analisis Data}

Metode analisis yang digunakan dalam penelitian ini yaitu analisis deskriptif, analisis regresi linier berganda, uji asumsi klasik, dan uji t untuk pengujian hipotesis.

\section{PEMBAHASAN}

\section{Statistik Diskriptif}

Berdasarkan hasil analisis diskriptif menunjukkan bahwa jumlah sampel $(\mathrm{N})$ dalam penelitian ini adalah 21 emiten pada perusahaan LQ 45 selama periode lima tahun yaitu 2009-2013. Variabel karakter eksekutif (KE) memiliki nilai minimum sebesar 0,015 dan nilai maximum sebesar 0,59773 dan secara rata-rata diperoleh sebesar 0,194 dengan standar deviasi sebesar 0,145. Nilai minimum variabel profitabilitas (ROA) sebesar 0,01093 dan nilai maximum sebesar 0,479 dan secara rata-rata diperoleh sebesar 0,135 dengan standar deviasi sebesar 0,105.

Variabel komite audit (KA) menunjukkan nilai minimum sebesar 3,00 dan nilai maximum sebesar 3,00 dan secara rata-rata diperoleh sebesar 3,914 dengan standar deviasi sebesar 1,194. Variabel komisaris independen (KI) menunjukkan nilai minimum sebesar 0,167 dan nilai maximum sebesar 0,800 dan secara rata-rata diperoleh sebesar 0,420 dengan standar deviasi sebesar 0,128. Variabel cash effective tax rate menunjukkan nilai rata-rata sebesar 0,256 dengan standar deviasi sebesar 0,099. Nilai minimum dari variabel ini sebesar 0,00024 dan nilai maximumnya sebesar 0,76953 .

\section{Regresi Linier Berganda}

Dalam penelitian ini metode analisis regresi linier berganda digunakan untuk mengetahui pengaruh dari variabel independen yang dinotasikan dengan (X), terdiri dari karakter eksekutif (KE), profitabilitas (ROA) komite audit (KA), komisaris independen (KI) terhadap variabel dependen (Y) yaitu cash effective tax rate (CETR). Model persamaan dalam penelitian ini adalah sebagai berikut:

$\mathrm{Y}=0,280+0,515 \mathrm{KE}-0,799 \mathrm{ROA}-0,002 \mathrm{KA}-0,024 \mathrm{KI}$

\section{Uji Asumsi Klasik}

\section{Uji Normalitas}

Berdasarkan uji normalitas menggunakan uji K-S (Kolmogorov Smirnov) diperoleh nilai 1,713 dengan probabilitas signifikansi sebesar 0.057. Nilai $p$ menunjukkan $>0.05$, hal ini berarti bahwa data residual berdistribusi normal atau dengan kata lain model regresi yang digunakan memenuhi asumsi normalitas. Kesimpulannya bahwa pada uji normalitas berdistribusi normal.

\section{Uji Heteroskedastisitas}

Hasil pengujian heteroskedastisitas pada tampilan grafik scatterplots menunjukan titik-titik tidak berkumpul tetapi menyebar secara acak baik di atas maupun di bawah angka 0 pada sumbu Y. Hal ini dapat disimpulkan bahwa tidak terjadi heteroskidastisitas pada model regresi pada penelitian ini.

\section{Uji Autokorelasi}

Hasil uji Durbin-Watson (D-W) yang diperoleh nilai sebesar 1,774 maka berdasarkan teori tersebut dapat diambil kesimpulan bahwa dalam model penelitian ini tidak terjadi autokorelasi, karena nilai D-W sebesar 1,809 dimana nilai 
tersebut diantara -2 dan +2 , sehingga Uji Autokorelasi terpenuhi.

\section{Uji Multikolinearitas}

Pada uji multikolinearitas menunjukkan bahwa tidak ada satupun variabel bebas yang memiliki nilai tolerance di bawah 0,10 dan nilai Variance Inflation Factor (VIF) di atas 10. Maka dapat disimpulkan bahwa antar variabel bebas tidak ada korelasi, karena nilai tolerance dari Karakter eksekutif $(\mathrm{KE})=0,111>0.10$, Profitabilitas $(\mathrm{ROA})=0,105$ $>0.10$, Komite Audit $(\mathrm{KA})=0,840>0.10$, Komisaris Independen $(\mathrm{KI})=0,973>0.10$, dan nilai VIF dari Karakter Eksekutif $(\mathrm{KE})=9,021<10$, Profitabilitas $(\mathrm{ROA})=9,533<$ 10 , Komite Audit $(\mathrm{KA})=1,190<10$, Komisaris Independen $(\mathrm{KI})=1,028$. Jadi dapat disimpulkan bahwa dalam penelitian ini tidak terjadi multikolineritas antara variabel bebas dalam model regresi.

\section{Koefisien Determinasi (R2)}

Hasil perhitungan $\mathrm{R}$ square diperoleh nilai koefisien determinasi (R2) sebesar 0,046 yang berarti bahwa kemampuan dari variabel-variabel independent KE, ROA, $\mathrm{KA}$ dan KI, dalam model regresi yang dikembangkan dapat menjelaskan variasi variabel dependent yaitu CETR (penghindaran pajak) sebesar 5\%, sementara itu 95\% dijelaskan oleh faktor-faktor lain di luarnya. Nilai standar error of estimate (SEE) sebesar 0,097, semakin kecil nilai SEE akan semakin tepat model regresi memprediksi variable dependen (Ghozali, 2013).

\section{Uji Hipotesis}

Uji t-Test dilakukan untuk melihat apakah secara terpisah variabel bebas mampu menjelaskan variabel dependen secara parsial. Berdasarkan hasil olahan data statistik pada tabel, maka dapat dilihat antara variabel independen secara parsial terhadap variabel dependen adalah:

Berdasarkan hasil regresi linear berganda pada pengaruh karakter eksekutif (KE) terhadap penghindaran pajak menunjukkan tingkat signifikansi sebesar $0,010<0.05$ yang artinya variabel karakteristik eksekutif (KE) berpengaruh terhadap penghindaran pajak. Artinya semakin eksekutif bersifat risk taker maka akan semakin tinggi penghindaran pajak yang dilakukan oleh manajemen.

Pengaruh profitabilitas (ROA) terhadap penghindaran pajak memiliki tingkat signifikansi sebesar $0,005<0,05$ yang artinya variabel profitabilitas (ROA) berpengaruh terhadap penghindaran pajak. Artinya semakin tinggi tingkat profitabilitas maka perusahaan (manajemen) cendrung melakukan penghindaran pajak.

Berdasarkan hasil regresi linear berganda, pengaruh komite audit (KA) terhadap penghindaran pajak menunjukkan tingkat signifikansi sebesar 0,851>0.05 yang artinya variabel komite audit tidak berpengaruh terhadap penghindaran pajak. Artinya adanya komite audit tidak akan mempengaruhi kecenderungan manajemen melakukan praktek penghindaran pajak.

Berdasarkan hasil regresi linear berganda pada pengaruh komisaris independen (KI) terhadap penghindaran pajak menunjukkan tingkat signifikansi sebesar 0,750>0.05 yang artinya variable komisaris independen (KI) tidak berpengaruh terhadap penghindaran pajak. Artinya semakin besar atau kecilnya proporsi dewan komisaris independen di suatu perusahaan tidak menyebabkan peningkatan atau penurunan penghindaran pajak suatu perusahaan.

\section{Simpulan dan Saran Penelitian \\ Simpulan}

Simpulan penelitian ini yaitu perusahaan yang memiliki karakter eksekutif risk taker dan profitabilitas yang tinggi cenderung melakukan penghindaran pajak, sedangkan komite audit dan komisaris independen tidak bias mempredikri kecenderungan perusahaan melakukan penghindaran pajak.

\section{Keterbatasan}

Dalam penelitian ini, penghindaran pajak yang diukur menggunakan cash effective tax rate hanya didasarkan dari laporan keuangan yang kurang menggambarkan keadaan riilnya karena data tentang penghindaran pajak yang sulit diperoleh.

\section{Saran}

Saran yang dapat diberikan untuk perbaikan dan kesempurnaan dari penelitian ini adalah sebagai berikut:

Bagi perusahaan agar dapat menjadi bahan untuk menambah pengetahuan dan wawasan tentang penghindaran pajak, sehingga manajemen perusahaan bisa merancang mekanisme pelaksanaan kelanjutan perusahaannya dengan baik, dengan tidak melakukan perencanaan pajak yang ilegal sehingga perusahaan tidak melakukan kecurangan pajak (tax evasion) yang dapat merugikan negara dan dapat membuat nama dan reputasi perusahaan tersebut menjadi buruk di mata publik.

Penelitian selanjutnya dapat menggunakan variabel lain yang diduga dapat mempengaruhi penghindaran pajak serta menambahkan variabel kontrol supaya penelitian tersebut lebih akurat. Selain itu disarankan untuk penelitian selanjutnya apabila data pajak penghasilan perusahaan memungkinkan untuk diperoleh, maka data tersebut dapat digunakan sebagai proksi penghindaran pajak yang lebih akurat.

\section{DAFTAR PUSTAKA}

Agusti, W. Y. 2014. Pengaruh Profitabilitas, Leverage, Dan Corporate Governance Terhadap Tax Avoidance.

Andriyani, N. K. 2008. Pengaruh Investment Opportunity Set (IOS), Mekanisme Corporate Governance, 
Ukuran Perusahaan dan Leverage pada Kualitas Laba.

Annisa, N. A. dan L. Kurniasih 2012. Pengaruh Corporate Governance Terhadap (Tax Avoidance).

Bapepam. 2000. Pembentukan Komite Audit, Surat Edaran Bapepam No. SE-03/PM/2000, http://www.bapepam.go.id (Dilayari 05 Oktober 2013).

Budiman, J dan Setiyono. 2012. Pengaruh Karakter Eksekutif Terhadap Penghindaran Pajak (Tax Avoidance).

Carolina, V., M. Natalia dan Debbianita 2014. Karakteristik Eksekutif Terhadap Tax Avoidance Dengan Leverage sebagai Variabel Intervening.

Chasbiandani, T dan D. Martani. 2012. Pengaruh Tax Avoidance jangka panjang Terhadap Nilai Perusahaan.

Dewi, N. N. K dan i. K. Jati. 2013. Pengaruh Karakter Eksekutif, arakteristik Perusahaan, Dan Dimensi Tata Kelola Perusahaan Yang Baik Pada Tax Avoidance.

Effendi, M. A. 2009. The Power Of Good Corporate Governance Terapi dan Implementasi : 2.

Hartono, J. 2008. Teori Portofolio dan Analisis Investasi, BPFE, Yogyakarta.

Haruman, T. 2008. Pengaruh Struktur Kepemilikan terhadap Keputusan Keuangan dan Nilai Perusahaan.

Herawaty, V. 2008. Peran Praktek Corporate Governance Sebagai Moderating Variable Dari Pengaruh Earnings Management Terhadap Nilai Perusahaan.

Hermuningsih, S. 2013. Pengaruh Profitabilitas, Growth opportunity, sruktur Modal terhadap nilai perusahaan.

Indrianto, N dan B. Supomo. 2002. Metodologi Penelitian Bisnis untuk Akuntansi dan Manajemen. Yogyakarta: BPFE-Yogyakarta.

Khoirunnisa. 2014. Pengaruh Corporate Governance Terhadap Tax Avoidance.

Kurniasih, T dan Sari, M. M. 2013. Pengaruh Profitabilitass, Leverage, Corporate Governance, Ukuran
Perusahaan, dan Kompensasi Rugi Fiskal pada Tax Avoidance.

LQ45. www.LO45.co.id diakses tanggal 5 September 2013. Ningsaptiti, R. 2010. Analisis Pengaruh Ukuran Perusahaan dan Mekanisme Corporate Governance Tehadap Manajemen Laba.

Nofrita, R. 2013. Pengaruh Profitabilitas Terhadap Nilai Perusahaan Dengan Kebijakan Deviden Sebagai Variabel Intervening.

Pedoman Umum Good Corporate Governance yang Dikeluarkan Oleh Komite Nasional Kebijakan Governance (KNKG) Tahun 2006.

Pohan, H. T. 2009. Analisis pengaruh istitusi, rasio tobin q, akrual pilihan, tarif efektif pajak, dan biaya pajak ditunda, terhadap penghindaran pajak pada perusahaan publik.

Prakosa, K. B. 2014. Pengaruh Profitabilitas, Kepemilikan Keluarga dan Corporate Governance Terhadap Penghindaran Pajak Di Indonesia.

Rusydi. M. K dan D. Martani. 2014. Pengaruh Struktur Kepemilikan terhadap Aggressive Tax Avoidance.

Sari, G. M. 2014. Pengaruh Corporate Governance, Ukuran Perusahaan, Kompensasi Rugi Fiskal Dan Struktur Kepemilikan Tehadap Tax Avoidance.

Swingly, C,dan I. M. Sukartha. 2014. Pengaruh Karakter Eksekutif, Komite Audit, Ukuran Perusahaan, Leverage dan Sales Growth pada Tax Avoidance. 